9 Letter to Alfred Pratt, August 26, 1865; Corr., 1:266.

10 Letter to Alfred Pratt, September 27, 1866; Corr., 1:287.

11 Letter to Louisa Whitman, March 5, 1867; Corr., 1:316.

12 Letter to Alfred Pratt, October 28, 1867; Corr., 1:345.

13 Letter to Louisa Whitman, January 22, 1867; Corr., 1:309.

14 Letter to Louisa Whitman, January 31, 1873; Corr., 2:194.

15 Letter to Martha Whitman, January 2, 1863; Corr., 1:62

16 Letter to Alfred Pratt, August 26, 1865; Corr., 1:265.

\title{
"GOING TO BED": A RECOVERED WHITMAN ARTICLE FROM THE BROOKLYN DAILY EAGLE
}

In the Brooklyn Daily Eagle of December 30, 1847, only weeks before he lost his job as editor, "one of the pleasantest sits" of his life for nearly two years, Walter Whitman published "Going to Bed," a short essay which generally anticipates both Section 11 of "Song of Myself" and "The Sleepers," first published in the 1855 Leaves of Grass. ${ }^{1}$ We can also hear in it an echo of the opium eater's "just-opened lips" ("the parted lips" of sleep) in Section 15 of "Song of Myself." In the voyeuristic passage about the "twenty-ninth bather," Whitman would describe a sexually frustrated Victorian woman who hides "handsome and richly drest aft the blinds of the window" as she looks down on twenty-eight young men bathing naked. In the Eagle essay, Whitman is more decorous in his invasiveness. His object is not "womanly life and all so lonesome," but "a young lady" who is naively sure of herself as a strong candidate for wedlock and its promise of happiness. It is quite possible that on this evening she has enjoyed the "pleasant company" of a suitor and so retires with "some agreeable ideas in her head." Once the light is out, "her fair, delicate form gently presses the couch — and like a dear, innocent lovely creature, as she is, she falls gently into sleep, with a sweet smile on her still sweeter face."

This is not, of course, one of the poet's proto-feminist women who know "how to swim, row, ride, wrestle, shoot, run, strike, retreat, advance, defend themselves" in "A Woman Waits for Me," but more like a character out of a novel of the day. Yet in peering in upon this apparent virgin to the point where her body "gently presses the couch," Whitman exhibits an early interest in going beyond conventional appearances. "Undrape!" he will announce in Leaves of Grass, "you are not guilty to me, nor stale nor discarded, / I see through the broadcloth and gingham whether or no." This future poet sees the naked truth.

The sketch then turns to a man "under the same circumstances" who "acts quite differently." Unlike his "dear, innocent lovely" counterpart, he is described as a "cannibal" whose every move "indicates the coarse, rough mould of his fallen nature." Whereas the female sleeper is something of an angel, he is closer to Shakespeare's Caliban in The Tempest. Or, more locally, he may remind us of the male lover in the underground version of "Once I Pass'd 
through a Populous City"- "one rude and ignorant man" instead of a woman casually met in the version Whitman approved for publication. Indeed, in its switching of genders, the sketch may also anticipate Whitman's female and male versions of "Once I Pass'd through a Populous City." Interestingly, this poet views the male sex as somehow "fallen," while the female remains almost spiritually aloft-and remote. In Leaves of Grass, of course, she comes down from her Victorian pedestal to join her male counterparts in the American democracy.

Finally, the essay's clearest anticipation is of "The Sleepers," which Richard Maurice Bucke described in his 1883 biography (heavily edited by Whitman) as "a representation of the mind during sleep - of connected, halfconnected, and disconnected thoughts and feelings as they occur in dreams. ..." The poet wanders all night in this dream-vision, gazing at the sleepers whose features are almost deathlike. "How solemn they look there, stretch'd and still," the narrator of "The Sleepers" will observe. In "Going to Bed," the editor of the Brooklyn Daily Eagle looks upon the slumberer and asks, "Is there not something preternaturally solemn about sleep? A something about it of dread and apprehension? The recumbent position - the closed eyes - the parted lips - the pallid countenance-the operations of a mind suspended - and the half-heard breath alone indicating the vital principle!"

We don't know exactly when Whitman began writing the poems of the first edition, but the editor was already "simmering" as he wrote "Going to Bed." He told John Townsend Trowbridge, "I was simmering, simmering, simmering; Emerson brought me to a boil." ${ }^{3}$ Indeed, exactly two weeks before publishing "Going to Bed," he alluded to having heard Emerson lecture on "Spiritual Laws." In the Eagle of December 15, 1847, he quoted from "the following striking paragraph" lines which also suggest the soporific splendor of "The Sleepers": "When the act of reflection takes place in the mind, when we look at ourselves in the light of thought, we discover that our life is embosomed in beauty. Behind us, as we go, all things assume pleasing forms, as clouds do afar off." In "The Sleepers," Whitman would declare that he could "dream all the dreams of the dreamers." In "Going to Bed," he takes the penultimate step into that state of unconsciousness in Leaves of Grass.

\section{Brooklyn Daily Eagle, December 30, 1847:}

GOING TO BED.-Going to bed we have always considered as one of the most sober, serious and solemn operations which a man can be engaged in during the whole twenty-four hours. With a young lady it is altogether a different sort of thing. When bed time arrives she trips up stairs with a candle in her hand, and-if she has had pleasant company during the evening - with some agreeable ideas in her head. The candle is placed on the toilet, and her luxuriant hair speedily emancipated from the thraldom of combs and pins. If she usually wears "water curls," or uses the "iron," her hair is brushed carefully from her forehead, and the whole mass compactly secured; if not, why then her lovely tresses are soon hid in innumerable bits of paper. This task accomplished, a night cap appears, edged may be with plain muslin, or may be with [levy?] lace, which hides all save her own sweet countenance. As soon as she ties the strings, probably she takes a peep in the glass, and half smiles and blushes at what she sees. The light is outher fair, delicate form gently presses the couch - and like a dear, innocent lovely creature, as she is, she falls gently into sleep, with a sweet smile on her still sweeter face. 
A man, of course, under the same circumstances, acts quite quite [sic] differently. Every movement in his chamber indicates the coarse, rough mould of his fallen nature. When all is ready, he snuffs the candle out with his fingers, like a cannibal, and then jumps into bed like a savage. For a few moments he thinks of all the pecadilloes he may have committed through the day-vows a vow [sic] to amend soon-groans - turns over - stretches himself - then all is silent - and then the heavy breathing of the slumberer. Is there not something preternaturally solemn about sleep? A something about it of dread and apprehension? The recumbent position - the closed eyes - the parted lipsthe pallid countenance-the operations of the mind suspended-and the half-heard breath alone indicating the vital principle!

Texas AEM University

JEROME LOVING

\section{NOTES}

1 Prose Works 1892, ed. Floyd Stovall (New York: New York University Press, 1963), 1:288. This essay is not included in The fournalism, ed. Herbert Bergman, Douglas A. Noverr, and Edward J. Recchia (New York: Peter Lang, 2003), vol. 2.

2 Richard Maurice Bucke, Walt Whitman (Philadelphia: David McKay, 1883), 171.

3 John Townsend Trowbridge, My Own Story (Boston: Houghton, Mifflin and Co., 1903), 367.

4 Reprinted in The Gathering of the Forces by Walt Whitman, ed. Cleveland Rodgers and John Black (New York: G. P. Putnam's Sons, 1920), 1:270-271; and The fournalism, 2:381-382. 